Original Article

\title{
METHYL 10-EPI-PHEOPHORBIDE A FROM MCF-7 CELLS ACTIVE LAYER OF THE INDONESIAN FICUS DELTOIDEA JACK LEAVES
}

\author{
ANGGIA MURNI' ${ }^{1}$, NOVRIYANDI HANIF ${ }^{2}{ }^{*}$, MASAKI KITA ${ }^{3}$, LATIFAH K. DARUSMAN ${ }^{1,2}$ \\ ${ }^{1}$ Tropical Biopharmaca Research Center, Bogor Agricultural University, Jalan Taman Kencana No. 3, Bogor 16128, Indonesia, ${ }^{2}$ Department \\ of Chemistry, Faculty of Mathematics and Natural Sciences, Bogor Agricultural University, Gedung Kimia Wing 1 Lantai 3, Jalan Tanjung \\ Kampus IPB Darmaga, Bogor 16680, Indonesia, ${ }^{3}$ Department of Applied Molecular Biosciences, Graduate School of Bioagricultural \\ Sciences, Nagoya University, Furo-cho, Chikusa, Nagoya 464-8610, Japan \\ Email: nhanif@apps.ipb.ac.id
}

Received: 29 Mar 2017 Revised and Accepted: 30 Jun 2017

\begin{abstract}
Objective: To isolate and elucidate a cytotoxic principle against breast tumor MCF-7 cells of the Indonesian terrestrial plant Ficus deltoidea Jack leaves.

Methods: F. deltoidea leaves collected at National Park of mount Gede-Pangrango, Indonesia have been subjected to chemical and biological work. $F$. deltoidea leaves were extracted with $96 \%$ aqueous ethanol $(\mathrm{EtOH})$ and was then partitioned into three layers $n$-hexane, dichloromethane $\left(\mathrm{CH}_{2} \mathrm{Cl}_{2}\right)$, and $n$-butanol $(n-\mathrm{BuOH})$. All layers were checked for their activity against breast tumor MCF-7 cells using MTT assay method. A portion of the most active layer was purified using open column chromatography to give fraction that has toxicity against zebra fish embryos. Based on the assay-guided isolation, compound 1 was isolated. The chemical structure of $\mathbf{1}$ was elucidated using nuclear magnetic resonance (NMR) and high-resolution mass spectrometry (HRMS) data as well as comparing data with literature.
\end{abstract}

Results: The $\mathrm{CH}_{2} \mathrm{Cl}_{2}$ layer of $F$. deltoidea leaves was found to inhibit breast tumor MCF-7 cells with $\mathrm{IC}_{50} 10 \mu \mathrm{g} / \mathrm{ml}$ which was the most toxic among the layers. A portion of the most active layer was purified using open column chromatography to give 7 fractions. The fraction 5 showed toxicity against zebrafish embryos (LC $5035 \mu \mathrm{g} / \mathrm{ml}, 48 \mathrm{hpf}$ ). This fraction was purified using high performance liquid chromatography (HPLC) octadecylsilyl (ODS) column with gradient elution $70 \%$ aqueous acetonitrile $(\mathrm{MeCN})$ to $100 \% \mathrm{MeCN}$ (linear gradient) for 40 min with UV detection at $254 \mathrm{~nm}\left(t_{R}=30.99 \mathrm{~min}\right)$ to give compound 1. The chemical structure of $\mathbf{1}$ was revealed as a chlorin-type compound named methyl 10-epi-pheophorbide A.

Conclusion: Methyl 10-epi-pheophorbide A was isolated for the first time from the active fraction of the Indonesian F. deltoidea leaves or tabat barito. The chemical structure including absolute stereochemistry was elucidated using NMR and HRMS data as well as by comparison with the literature values. The ${ }^{13} \mathrm{C}$ NMR data has been added to complete the previous report.

Keywords: Ficus deltoidea, NMR, HRMS, Cytotoxic, Zebrafish embryos, Alkaloid, Chlorin, Conformational analysis

(C) 2017 The Authors. Published by Innovare Academic Sciences Pvt Ltd. This is an open access article under the CC BY license (http://creativecommons.org/licenses/by/4.0/) DOI: http://dx.doi.org/10.22159/ijpps.2017v9i8.18750

\section{INTRODUCTION}

Breast cancer is notorious. Among the cancer diseases, breast cancer is the second most common cancer worldwide and the fifth most common cause of cancer death as well as the leading cause of cancer death in women [1]. Terrestrial natural products have proven their activity for curing childhood leukemia, testicular teratoma and Hodgkin's disease by using vinblastine and vincristine, the alkaloids isolated from terrestrial plant Catharanthus roseus. Taxol, the most significant drug, isolated from the Pacific yew Taxus brevifolia has efficacy against various solid tumours (lung, colon, skin, kidney, ovary, brain, breast and prostate). The library of significant natural products against breast cancer is still a few, therefore search for anticancer drugs is required combining with elucidating biologically system of cancer cells [2]. The use of herbal remedies on the basis of ethnopharmacology study for treatment cancer disease is required because the substances can be hoped to overcome the current side effect such as hair loss, bone marrow suppression, vomiting, rash, and inflammation of the mouth $[3,4]$.

The plant of $F$. deltoidea Jack known as tabat barito (Indonesia), mas cotek (Malaysia) or kangkalibang (Africa) is a medicinal plant widely distributed in Southeast Asia especially in Indonesia and Malaysia. Botanically, Ficus genus belongs to the family of Moraceae and is one of the biggest genera of Angiospermae [5]. The plant has been reported as traditional medicine to prevent and cure diseases such as diarrhea, sores lung watery, diabetes, high blood pressure, weak heart, cardiovascular and cure skin diseases [6]. Research showed that the extracts of $F$. deltoidea have effects as antioxidant $[7,8]$, antidiabetic [7, 9], anti-inflammatory [10, 11], antinociceptive [12], antibacterial [13-15], anti melanogenic [16], antiherpes simplex virus type 1 (HSV-1), antiproliferation in 3T3-L1 adipocytes $[17,18]$ and antiangiogenic effect [19] to name a few. In our previous research, the result revealed that extracts of $F$. deltoidea leaves inhibited the growth of breast tumor in mice and inhibit enzyme tyrosine kinase activity [20].

A few chemical metabolites have been isolated and elucidated from $F$. deltoidea leaves. Moretenol and epi-lupeol [21], terpenoid-type compounds, were isolated from Malaysian F. deltoidea leaves. The latter was also found in West Sumatera [15]. In addition, vitexin and isovitexin, flavonoid-type compounds were obtained from $F$. deltoidea leaves collected at Tapah, Perak, Malaysia [22]. The molecules showed in vivo $\alpha$ glucosidase inhibition. Moreover, the Ficus genus contained alkaloid such as chlorin as ficusmicrochlorin A-C [23] and ficuschlorin A-D [24] have been discovered from Taiwanese Ficus microcarpa. All the compounds were elucidated using detailed analysis of 1D and 2D NMR spectroscopy as well as MS data. Chlorins are known as natural pigments and have been used a traditional medicine and therapeutic purpose for a long time [25]. Their special structure, which are composed of cyclic tetrapyrroles, exhibited as photosensitizers for use in photodynamic therapy (PDT), a physical treatment for cancer with a combination of photosensitizers and light [26]. Mechanistic studies showed that pheophorbide A, a chlorin from Scutellaria barbata induced apoptosis in Hep3B cells, a viral-induced hepatoma cell line. However, it was found to be non-toxic in normal human liver cells WRL-68. In Chinese clinics, S. barbata has been used in the treatment of liver cancer, digestive system cancers, lung cancer and breast cancer [27].

Pharmaceutical and phytochemical studies have verified the traditional uses of $F$. deltoidea, nevertheless, there is a necessity to investigate the chemical or bioactive compounds that responsible 
for certain properties. Currently, there is a great interest in the phytochemical content and potential beneficial effect of Indonesian medicinal plants including $F$. deltoidea. In our continuing interest on bioactive molecules from terrestrial plant [28], the Indonesian plants $F$. deltoidea or tabat barito leaves were examined.

\section{MATERIALS AND METHODS}

\section{Materials}

The leaves of sample collected at National Park of mount Gede Pangrango, Cibodas Indonesia in June 2013 were identified as Ficus deltoidea Jack by Herbarium Bogoriense, Research Center for Biology, Indonesian Institute of Science (LIPI). A voucher of the specimen (NYH-01-A) was deposited in Department of Chemistry, Bogor Agricultural University.

\section{Chemicals and equipment}

Nuclear magnetic resonance (NMR) spectra were recorded on a Bruker Biospin AVANCE 600 spectrometer $\left(600 \mathrm{MHz}\right.$ for ${ }^{1} \mathrm{H}$ and 150 $\mathrm{MHz}$ for ${ }^{13} \mathrm{C}$ ) and on JEOL JNM-ECA500 (500 $\mathrm{MHz}$ for ${ }^{1} \mathrm{H} \mathrm{NMR}$ ) spectrometer. Chemical shifts $(\delta)$ were referenced to TMS or $\mathrm{CDCl}_{3}$ signals $\left({ }^{1} \mathrm{H} \delta 7.26,{ }^{13} \mathrm{C} \delta 77.16\right)$. All chemical shifts $(\delta)$ are given in ppm and coupling constants $\left(\right.$ ) are in $\mathrm{Hz}$. The ${ }^{13} \mathrm{C}$ NMR data were determined by HSQC and HMBC experiments. HRESIMS mass spectra were measured on AccuTOF CS spectrometer (JEOL) with reserpine as internal standard $(\mathrm{m} / \mathrm{z} 609.28121$ for $[\mathrm{M}+\mathrm{H}])$. High-performance liquid chromatography separations were carried out on a Shimadzu UFLC-20 AD intelligent pump equipped with an SPD-M20A diode array detector. A column used for HPLC were Shim-pack VP-ODS (4.6 x 250 $\mathrm{mm}$ ). Analytical thin layer chromatography (TLC) was performed on Merck silica gel 60 F254 plates and monitored with anisaldehyde and a UV lamp at $254 \mathrm{~nm}$. All solvents used were of analytical grade.

\section{Extraction and isolation}

The $F$. deltoidea fresh leaves $(1 \mathrm{~kg}$ ) were macerated in $96 \%$ aqueous $\mathrm{EtOH}$ for $24 \mathrm{~h}$ and repeated for three times. The EtOH extract $(16 \mathrm{~g})$ was then partitioned between ethyl acetate (EtOAc)-water $\left(\mathrm{H}_{2} \mathrm{O}\right)$ (2:1) then EtOAc layer partition between hexane and 90\% methanol ( $\mathrm{MeOH})-\mathrm{H}_{2} \mathrm{O}$. The aqueous $\mathrm{MeOH}$ was partitioned between $\mathrm{CH}_{2} \mathrm{Cl}_{2}$ and $50 \% \mathrm{MeOH}-\mathrm{H}_{2} \mathrm{O}$. The $\mathrm{H}_{2} \mathrm{O}$ layer from partition EtOH extract was then extracted with $n$-BuOH. The three extracts (hexane, $\mathrm{CH}_{2} \mathrm{Cl}_{2}$, and $n$-BuOH) were checked their activity against MCF-7 tumor cells.

The $\mathrm{CH}_{2} \mathrm{Cl}_{2}$ layer $(0.48 \mathrm{~g})$ was purified using open column chromatography with silica gel as the stationary phase and eluted with increasing gradient polarity, hexane- $\mathrm{CH}_{2} \mathrm{Cl}_{2}-\mathrm{MeOH}$ to give 7 fractions. Major fraction was tested toxicity assay against zebra fish embryos. In addition, a portion of the fifth fraction was checked its ${ }^{1} \mathrm{H}$ NMR and then separated by HPLC with a C18 column (4.6 x 250 $\mathrm{mm}$ ) using gradient elution $80 \%$ aqueous $\mathrm{MeOH}$ to $100 \% \mathrm{MeOH}$ for $45 \mathrm{~min}$ to give 5 subfractions. The fourth subfraction $(5.2 \mathrm{mg})$ was purified using a C18 column $(4.6 \times 250 \mathrm{~mm})$ with gradient elution with $70 \%$ aqueous $\mathrm{MeCN}$ to $100 \% \mathrm{MeCN}$ for $40 \mathrm{~min}$ at flow rate 1 $\mathrm{ml} / \mathrm{min} \mathrm{UV}$ detection $254 \mathrm{~nm}$ to give $0.8 \mathrm{mg}$ of pure methyl 10-epi pheophorbide A (1) $\left(t_{R}=30.99 \mathrm{~min}\right)$.

\section{Cytotoxicity assay against breast tumor cells MCF7 cells}

Growing cells of MCF 7 (ATCC® HTB22) were suspended in DMEM containing fetal bovine serum and penicillin-streptomycin. Samples dissolved in acetone were added into the 96 wells tissue culture plate with 5000 cells/well. The cells were incubated at $37^{\circ} \mathrm{C}$ for $48 \mathrm{~h}$ in a $\mathrm{CO}_{2}$ incubator with a humidified atmosphere containing $5 \% \mathrm{CO}_{2}$. The cell numbers were counted by the MTT method. Optical density at $565 \mathrm{~nm}$ was measured with a microplate reader.

Table 1: NMR data of $1^{\text {a }}$

\begin{tabular}{|c|c|c|}
\hline No. & $\delta \mathrm{C}$, multiplicity & $\delta \mathrm{H}$, multiplicity, ( in $\mathrm{Hz}$ ) \\
\hline 1 & 141.8, C & \\
\hline 2 & $131.9, \mathrm{C}$ & \\
\hline $2^{1}$ & $12.1, \mathrm{CH}_{3}$ & $3.40, \mathrm{~s}$ \\
\hline 3 & $136.4, \mathrm{C}$ & \\
\hline $3^{1}$ & $129.0, \mathrm{CH}$ & $8.00, \mathrm{dd}(17.8,11.5)$ \\
\hline \multirow[t]{2}{*}{$3^{2}$} & 122.6, $\mathrm{CH}_{2}$ & $6.30, \mathrm{dd}(17.8,1.2)$ \\
\hline & & 6.19, dd $(11.5,1.2)$ \\
\hline 4 & $134.5, \mathrm{C}$ & \\
\hline 5 & $97.3, \mathrm{CH}$ & $9.40, \mathrm{~s}$ \\
\hline 6 & $155.8, \mathrm{C}$ & \\
\hline 7 & 136.1, C & \\
\hline $7^{1}$ & $11.1, \mathrm{CH}_{3}$ & $3.25, \mathrm{~s}$ \\
\hline 8 & $145.4, \mathrm{C}$ & \\
\hline $8^{1}$ & $19.7, \mathrm{CH}_{2}$ & $3.70, \mathrm{q}(7.8)$ \\
\hline $8^{2}$ & $17.8, \mathrm{CH}_{3}$ & $1.70, t(7.8)$ \\
\hline 9 & $150.2, \mathrm{C}$ & \\
\hline 10 & 104.2, CH & $9.54, \mathrm{~s}$ \\
\hline 11 & 137.5, C & \\
\hline 12 & 132.0, C & \\
\hline $12^{1}$ & $12.1, \mathrm{CH}_{3}$ & $3.69, \mathrm{~s}$ \\
\hline 13 & $129.4, \mathrm{C}$ & \\
\hline $13^{1}$ & 189.5, C & \\
\hline $13^{2}$ & $61.0, \mathrm{CH}$ & $6.25, \mathrm{~s}$ \\
\hline $13^{3}$ & $170.0, \mathrm{C}$ & \\
\hline $13^{4}$ & $52.6, \mathrm{CH}_{3}$ & 3.87, s \\
\hline 14 & 149.7, C & \\
\hline 15 & $105.0, \mathrm{C}$ & \\
\hline 16 & 161.5, C & \\
\hline 17 & $50.5, \mathrm{CH}$ & 4.20, ddd $(9.1,3.2,2.0)$ \\
\hline \multirow[t]{2}{*}{$17^{1}$} & $31.2, \mathrm{CH}_{2}$ & $2.62, \mathrm{~m}$ \\
\hline & & $2.50, \mathrm{~m}$ \\
\hline $17^{2}$ & $30.2, \mathrm{CH}_{2}$ & $2.22, \mathrm{~m}$ \\
\hline $17^{3}$ & $17.3, \mathrm{C}$ & \\
\hline $17^{4}$ & $52.0, \mathrm{CH}_{3}$ & $3.56, \mathrm{~s}$ \\
\hline 18 & $50.1, \mathrm{CH}$ & $4.46, \mathrm{dq}(2.0,7.3)$ \\
\hline $18^{1}$ & $23.1, \mathrm{CH}_{3}$ & $1.80, \mathrm{~d}(7.3)$ \\
\hline 19 & $172.2, \mathrm{C}$ & \\
\hline 20 & $93.2, \mathrm{CH}$ & $8.56, \mathrm{~s}$ \\
\hline
\end{tabular}

${ }^{\mathrm{a}} 600 \mathrm{MHz}{ }^{1} \mathrm{H}$ NMR and $150 \mathrm{MHz}{ }^{13} \mathrm{C} \mathrm{NMR}$ in $\mathrm{CDCl}_{3}$. 


\section{Toxicity assay using embryos zebrafish}

Wild-type zebrafish $D$. rerio was supplied by the fish local market. The mature zebrafish aged between 5 and 24 mo was used for egg production. The spawning and fertilization took place in the morning within $1 \mathrm{~h}$. The eggs were kept in the water which was used for spawning with a bunch of Terminalia catappa as an antibacterial agent. The fertilized and divided normally eggs were selected. Eggs with obvious anomalies or damaged membranes were discarded. Sample stock solution was made in $500 \mu \mathrm{g} / \mathrm{ml}$ and diluted with the appropriate solvent to give a series of concentration $12.5,25,50$, and $100 \mu \mathrm{g} / \mathrm{ml}$. DMSO was added when the extract was difficult to dissolve. Ten embryos with $48 \mathrm{~h}$ post fertilization (hpf) were added to each well which was previously added of fresh water and sample. The experiment was performed in three times. The multiwell was incubated for $24 \mathrm{~h}$. The dead embryo was counted and its $\mathrm{LC}_{50}$ was calculated by using statistical software SPSS 23.0.

\section{Conformational analysis}

Conformational searches were performed with Spartan '14 (Wavefunction Inc.) using a commercially available PC. The model was constructed on a graphical user interface considering an equilibrium geometry at ground state using MMFF.

\section{RESULTS}

A sample of $F$. deltoidea leaves was thoroughly extracted with EtOH. After concentration, the residue was partitioned with $n$-hexane, $\mathrm{CH}_{2} \mathrm{Cl}_{2}$, and $n-\mathrm{BuOH}$, respectively. The $\mathrm{CH}_{2} \mathrm{Cl}_{2}$ layer was the most toxic against tumor cells MCF-7 with IC50 $10 \mu \mathrm{g} / \mathrm{ml}$, while the $n$-hexane and $n$ - $\mathrm{BuOH}$ layer showed activity against the cells with $\mathrm{IC}_{50}>100$ and $>1000 \mu \mathrm{g} / \mathrm{ml}$, respectively. The purification of the $\mathrm{CH}_{2} \mathrm{Cl}_{2}$ layer was performed using open column chromatography followed by HPLC ODS with gradient elution $70 \%$ aqueous MeCN to $100 \%$ MeCN (linear gradient) for 40 min with UV detection at $254 \mathrm{~nm}$ to give compound $\mathbf{1}$ as methyl 10epi-pheophorbide A ( $\left.t_{R}=30.99 \mathrm{~min}\right)$ with the following properties: dark green solid, ${ }^{1} \mathrm{H}$ NMR $\left(\mathrm{CDCl}_{3}, 600 \mathrm{MHz}\right)$ and HRESIMS $[\mathrm{M}+\mathrm{Na}]^{+} 629.2739\left(\right.$ calcd for $\left.\mathrm{C}_{36} \mathrm{H}_{38} \mathrm{~N}_{4} \mathrm{O}_{5} \mathrm{Na} 629.2740\right)$.

\section{DISCUSSION}

The $\mathrm{CH}_{2} \mathrm{Cl}_{2}$ layer of $F$. deltoidea leaves inhibited breast tumor MCF-7 cells using MTT assay method. The half maximum inhibitory concentration ( $\mathrm{IC}_{50}$ ) was $10 \mu \mathrm{g} / \mathrm{ml}$ which was the most toxic among the layers. The active layer was purified using open column chromatography to give fraction 5 that has toxicity activity against zebra fish embryo. The half maximum lethal concentration ( $\mathrm{LC}_{50}$ ) was $35 \mu \mathrm{g} / \mathrm{ml}$. Based on assay guided isolation, we found compound 1 after purification using HPLC.

Compound 1 was obtained as a dark green solid. The high-resolution mass spectrometry using electrospray ionization (HR-ESIMS) showed $[\mathrm{M}+\mathrm{Na}]+629.2739(\Delta+0.1 \mathrm{mmu})$, which was consistent with the molecular formula $\mathrm{C}_{36} \mathrm{H}_{38} \mathrm{~N}_{4} \mathrm{O}_{5}$ indicating 19 degrees of unsaturation number. The ${ }^{1} \mathrm{H}$ NMR of compound 1 showed key signals for three aromatic methine groups $\left[\delta_{\mathrm{H}} 9.40(\mathrm{H}-5), 9.54(\mathrm{H}-10)\right.$, $8.56(\mathrm{H}-20)]$, one conjugated vinyl group $\left[\delta_{\mathrm{H}} 8.00\left(\mathrm{H}-3^{1}\right), 6.30\left(\mathrm{H}-3^{2}\right)\right.$ and $\left.6.19\left(\mathrm{H}-3^{2}\right)\right]$, three aromatic methyl groups $\left[\delta_{\mathrm{H}} 3.69\left(\mathrm{H}-12^{1}\right)\right.$, $3.40\left(\mathrm{H}-2^{1}\right)$ and $\left.3.25\left(\mathrm{H}-7^{1}\right)\right]$, two methyl ester groups $\left[\delta_{\mathrm{H}} 3.87(\mathrm{MeO}-\right.$ $\left.\left.13^{4}\right), 3.56\left(\mathrm{MeO}-17^{4}\right)\right]$, and one ethyl group $\left[\delta_{\mathrm{H}} 3.69\left(\mathrm{H}-8^{1}\right)\right.$ and 1.70 $\left.\left(\mathrm{H}-8^{2}\right)\right]$. The ${ }^{1} \mathrm{H}$ NMR data of 1 showed close similarity with that of phaeophytin A. Compound 1 possessed additional ${ }^{1} \mathrm{H}$ NMR signal of $\delta_{\mathrm{H}} 3.56$ assigned as methyl ester $\left(\mathrm{H}-17^{4}\right)$ replacing the phytyl branch in phaeophytin $\mathrm{A}$. The ${ }^{13} \mathrm{C}$ NMR was determined by HMQC and $\mathrm{HMBC}$ spectra due to the small amount of material available. Observed ${ }^{13} \mathrm{C}$ NMR data for 1 was close resemblance with phaeohytin A [29] except for the presence of methoxy group at $\mathrm{C}-17^{4}$ as in 1 .

First, confirmation of the almost planar structure of porphyrin moiety was explained. The NOESY correlation observed between $\mathrm{H}-18\left(\delta_{\mathrm{H}}\right.$ 4.46) and $\mathrm{H}-17^{2}\left(\delta_{\mathrm{H}} 2.50\right.$ and 2.22$)$ was inferred that $\mathrm{H}-18$ was the same face as $\mathrm{H}-17^{2}$. Another key NOESY signal between $\mathrm{H}-17\left(\delta_{\mathrm{H}} 4.20\right)$ and $\mathrm{H}-13^{2}\left(\delta_{\mathrm{H}} 6.30\right)$ was observed, which proved that two methyl esters were the same $\beta$-orientation. Moreover, the configuration at $\mathrm{C}-13^{2}$ was determined by Inhoffen method [30, 31]. The method described the deshielding effect of a functional group side chain at $\mathrm{C}-13^{2}$ against $\mathrm{H}-17$ leading to the determination of its configuration $R$ or $S$. If the $13^{2}-\mathrm{CO}_{2} \mathrm{Me}$ is located on the same side of the molecular plane as $17-\mathrm{H}$, it gives the deshilded effect and has the $R$ configuration. On the other hand, when the $13^{2}-\mathrm{CO}_{2} \mathrm{Me}$ has the opposite configuration $S$, the $17-\mathrm{H}$ signal is little affected $(\Delta \delta 0.1)$ by the presence of the functional group.

The ${ }^{1} \mathrm{H}$ NMR signal of $\mathrm{H}-17$ is distinctly little affected by the presence of the $13^{2}-\mathrm{CO}_{2} \mathrm{Me}$ and shows the chemical shift around $\delta_{\mathrm{H}} 4.20$ $\left(\mathrm{CDCl}_{3}\right)$. The shift observed for $\mathrm{H}-17$ was very small $(\Delta \delta 0.01)$ compared with the literature [29] and therefore, it was assigned as $S^{*}[30,31]$. The structure of 1 was concluded as in fig. 1 .
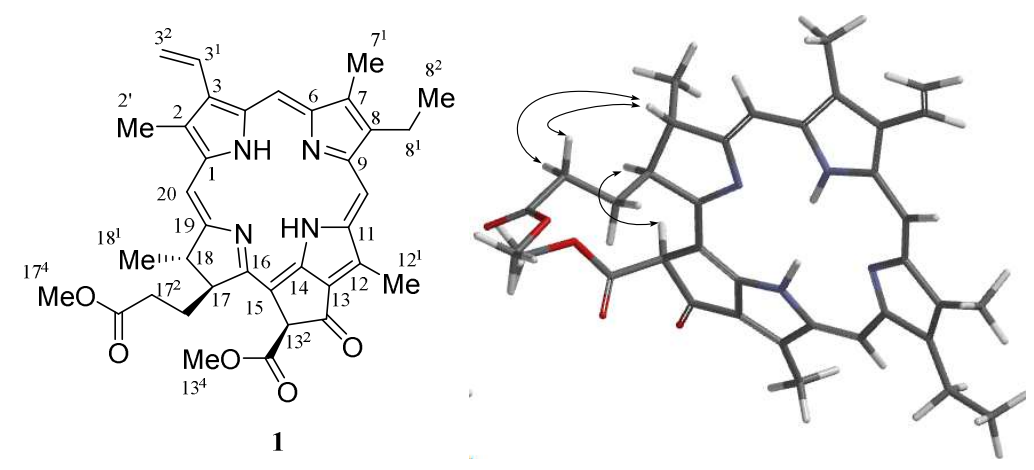

Fig. 1: Structure and key NOESY signals of 1 (3D model) measured in $\mathrm{CDCl}_{3}$

As a result, the structure of compound $\mathbf{1}$ was identical to methyl 10-epi-pheophorbide A that was originally isolated from spinach leaves [32] and later in Ficus microcarpa leaves [23, 24]. Meanwhile, this is the first report of methyl 10-epi-pheophorbide A from F. deltoidea. We also supplied the complete ${ }^{13} \mathrm{C}$ NMR data for 1 to equip the previous report [32]. Due to a minute amount of the compound $(0.8 \mathrm{mg})$, we could not establish the cytotoxicity against MCF-7 tumor cells.

\section{CONCLUSION}

Methyl 10-epi-pheophorbide A (1) was isolated from a MCF-7 cell active layer of the Indonesian Ficus deltoidea Jack leaves or tabat barito. The chemical structure including absolute stereochemistry was elucidated using NMR and HRMS data and by comparison with the literature values. This type of compound could be considered as an antitumor agent from $F$. deltoidea based on reported of its activity as antiproliferative on hepatoma Hep3B cells.

\section{ACKNOWLEDGEMENT}

We would like to thank to Resi Ardianti who performed zebrafish embryos assay. This work was partly supported by BOPTN program, The Ministry of Education and Culture through Tropical Biopharmaca Research Center LPPM Bogor Agricultural University, Indonesia. 


\section{AUTHOR'S CONTRIBUTION}

AM performed extraction, purification using open column chromatography and HPLC, MCF-7 cell assay, interpretation of the data, and wrote the paper. NH contributed for sample collection, conceived design experiments, interpretation of the data, supervised the laboratory work, and wrote the paper. MK contributed for HRMS and NMR measurement as well as searching structure databases. LKD initiated for research theme. All the authors have read the final manuscript and approved the submission.

\section{CONFLICT OF INTERESTS}

The authors declare no conflict interest

\section{REFERENCES}

1. Hutchinson L. Breast cancer: challenges, controversies, breakthroughs. Nat Rev Clin Oncol 2010;7:669-70.

2. Mann J. Natural products in cancer chemotherapy: the past, present and future. Nat Rev Cancer 2002;2:143-8.

3. Srinivasahan V, Durairaj B. In vitro cytotoxic and apoptotic activity of polysaccharide rich Morinda citrofolia fruit on MCF-7 cells. Asian J Pharm Clin Res 2015;8 Suppl 2:190-3.

4. Haridas R, Manorama S, Thekkan S. In vitro cytotoxicity activity of Malaxis rheedii SW methanol extracts against Hela cell line and MCF-7 cell line. Asian J Pharm Clin Res 2016;9 Suppl 6:244-6.

5. Loutfy MHA, Karakish EAK, Khalifa SF, Mira ERA. Numerical taxonomic evaluation of leaf architecture of some species of genus Ficus L. Int J Agric Biol 2005;7:352-7.

6. Bunawan H, Amin NM, Bunawan SN, Baharum SN, Noor NM. Ficus deltoidea Jack: a review on its phytochemical and pharmacological importance. Evid Based Complement Alternat Med 2014. http://dx.doi.org/10.1155/2014/902734

7. Hakiman $M$, Maziah $M$. Non-enzymatic and enzymatic antioxidant activities in aqueous extract of different Ficus deltoidea accessions. J Med Plant Res 2009;3:120-31.

8. Omar $\mathrm{MH}$, Mullen W, Crozier A. Identification of proanthocyanidin dimers and trimmers, flavone $C$-glycosides, and antioxidants in Ficus deltoidea, a Malaysian herbal tea. J Agric Food Chem 2011;59:1363-9.

9. Rosnah J, Khandaker MM, Boyce AN. Ficus deltoidea: a review on the background and recent pharmacological potential. J Agron 2015;14:310-8.

10. Zunoliza A, Khalid H, ZhariI, Rasadah MA, Mazura P, Fadzureena J, et al. Evaluation of extracts of the leaf of three Ficus deltoidea varieties for antioxidant activities and secondary metabolites. Pharmacogn Res 2009;1 Suppl 4:216-23.

11. Zakaria ZA, Hussain MK, Mohamad AS, Abdullah FC, Sulaiman MR. Anti-inflammatory activity of the aqueous extract of Ficus deltoidea. Biol Res Nurs 2012;14:90-7.

12. Sulaiman MR, Hussain MK, Zakaria ZK, Somchit MN, Moin S, Mohamad AS, et al. Evaluation of the antinociceptive activity of Ficus deltoidea aqueous extract. Fitoterapia 2008;79:557-61.

13. Uyub AM, Nwachukhu IN, Azlan AA, Fariza SS. In vitro antibacterial activity and cytotoxicity of selected medicinal plant extracts from Penang island Malaysia on metronidazoleresistant helicobacter pylori and some pathogenic bacteria. Ethnobot Res Appl 2010;8:95-106.

14. Samah OA, Tarwiyah N, Zaidi A, Sule AB. Antimicrobial activity of Ficus deltoidea Jack. (Mas Cotek). Pak J Pharm Sci 2012;25:675-8.

15. Suryati, Nurdin H, Dachriyanus, Lajis MNH. Structure elucidation of the antibacterial compound from Ficus deltoidea Jack leaves. Indones J Chem 2011;11:67-70.

16. Oh MJ, Hamid MA, Ngadiran S, SeoYK, Sarmidi MR, Park CS. Ficus deltoidea (Mas cotek) extract exerted anti-melanogenic activity by preventing tyrosinase activity in vitro and by suppressing tyrosinase gene expression in B16F1 melanoma cells. Arch Dermatol Res 2011;303:161-70.

17. Sakdarat S, Shuyprom A, Pientong C, Ekalaksananan T, Thongchai S. Bioactive constituents from the leaves of Clinacanthus nutans Linda. Bioorg Med Chem 2009;17:1857-60.

18. Wua SJ, Ng LT, Wang GH, Huang YJ, Chen JL, Sun FM. Chlorophyll a, an active antiproliferative compound of Ludwiga octovalvis, activates the CD95 (APO-1/CD-95) system and AMPK pathway in 3T3-L1 cells. Food Chem Toxicol 2010;48:716-21.

19. Shafaei A, Muslim NS, Nassar ZD, Aisha AFA, Majid AMSA, Ismail Z. Antiangiogenic effect of Ficus deltoidea Jack standardized leaf extracts. Trop J Pharm Res 2014;13 Suppl 5:761-8.

20. Darusman LK, Iswantini D, Djauhari E, Heryanto R. Estrak tabat barito berkhasiat anti-tumor: kegunaan sebagai jamu, ekstrak terstandar dan fitofarmaka. Indonesian unpublished patent P00 2003 00385; 2003.

21. Lip JM, Hisham DN, Zaidi JA, Musa Y, Ahmad AW, Normah A. Isolation and identification of moretenol from Ficus deltoidea leaves. J Trop Agric Food Sci 2009;37:195-201.

22. Choo CY, Sulong NY, Man F, Wong TW. Vitexin and isovitexin from the leaves of Ficus deltoidea with in vivo $\alpha$-glucosidase inhibition. J Etnopharmacol 2012;142:776-81.

23. Lin HY,Chiu HL, Lu TL, Tzeng CY, Lee TH, Lee CK, et al. Ficusmicrochlorin A-C, two new methoxy lactone chlorins and an anhydride chlorin from the leaves of Ficus microcarpa. Chem Pharm Bull 2011;59:113-6.

24. Lin YH, Chiu HL, Lan YH, Tzeng CY, Lee TH, Lee CK, et al. Ficuschlorins A-D, lactone chlorins from the leaves of Ficus microcarpa. Chem Biodivers 2011;8:1701-6.

25. Ferruzzi MG, Blakeslee J. Digestion, absorption, and cancer preventative activity of dietary chlorophyll derivatives. Nutr Res 2007;27:1-12.

26. Wongsingkongman $\mathrm{P}$, Brossi A, Wang HK, Bastow KF, Lee KH. Antitumor agents. Part 209:Pheophorbide-a derivatives as photo-independent cytotoxic agents. Bioorg Med Chem 2002;10:583-91.

27. Chan JY, Yang PM, Hon PM, An SW, Tsui SK, Wave MM. Pheophorbide a, a major antitumor component purified from Scutellaria barbata, induces apoptosis in human hepatocellular carcinoma cells. Planta Med 2006;72:28-33.

28. Hanif N, Irawadi TT, Affandi H, Read RW, Nomura T. Artonol B, an isoprenylated phenol from the stem-bark of Terap (Artocarpus anisophyllus Miq). Presented at National Symposium on Natural Product Chemistry VII, Depok, Indonesia; 1999. p. 386-90.

29. Matsuo A, Ono K, Hamasaki K, Nozaki H. Phaeophytins from a cell suspension culture of the liverwort Plagiochila ovalifolia. Phytochemistry 1996;42:427-30.

30. Nakatani Y, Ourisson G, Beck JP. Chemistry and biochemistry of Chinese drugs VII: cystostatic phephytins from silkworm excreta, and derived photocytotoxicity pheophorbides. Chem Pharm Bull 1981;29:2261-9.

31. Wolf H, Brockmann HJr, Biere H, Inhoffen HH. Darstellung der diastereomeren 10-Methoxy-(pyro)-methyl-phaophorbide a und bestimmung der relativen Konfiguration am C-Atom 10. Liebigs Ann Chem 1967;704:208-25.

32. Ellsworth PA, Storm CB. Methyl 10-ephipheophorbide a: an unusual epimeric stability relative to chlorophyll a or a'. J Org Chem 1978;43:281-3.

\section{How to cite this article}

- Anggia Murni, Novriyandi Hanif, Masaki Kita, Latifah K Darusman. Methyl 10-epi-pheophorbide a from MCF-7 cells active layer of the Indonesian Ficus deltoidea jack leaves. Int J Pharm Pharm Sci 2017;9(8):183-186. 